\title{
Efisiensi Pemasaran Komoditas Lada di Kabupaten Konawe Ditinjau Dari Perspektif Ekonomi Islam
}

\author{
Leni Saleh \\ Program Studi Agribisnis dan Agroindustri Fakultas Pertanian \\ Universitas Lakidende \\ Email:Cici raslin@yahoo.co.id
}

\begin{abstract}
The purpose of this study to determine the efficiency of the marketing of pepper in Konawe viewed from the perspective of Islamic economic. Method of sampling is done by simple random sampling as many as 45 respondents out of the total population, while traders villages (PPD) were 3 people and traders districts (PPK) have as many as two people in the census.

The result of the study conluded that the marketing efficiency of the in the village Unaasi. Anggaberi districts in Konawe through two (2) marketing channels, namely :Marketing channel I, from farmers producing $\longrightarrow$ PPK $\longrightarrow$ of inter-island trader, with the marketing margin 97,46\%. Marketing channel II, from farmers producing $\longrightarrow$ PPD $\rightarrow$ PPK $\longrightarrow$ of inter-island trader, with the marketng margin $97,40 \%$.

From the analysis it can be conluded that the marketing activities on the commodity pepper in Konawe already efficient, but needs to be improved. In terms of the service has been satisfactory. Viewed from the perspective of Islamic economy againts commodity pepper were done by farmers/producers, the views of the marketing is in conformity with the two assumptions that are under the influence of the spirit of Islam that is the assumption of economic rationality and selling without any coercion. Since marketing of commodities pepper is the efforts made by farmers/producers in order to maximize satisfaction and fulfillment. In marketing the pepper that they (farmers) produced by choosing their own marketing channels they want to sell pepper production. Transactions conducted by this farmer also insyaAllah avoid speculative transactions, transactions that are not clear (Gharar), usury and false (evil deeds).
\end{abstract}

Key words: Marketing Efficiency, the Islamic Economiy, and Pepper. 


\begin{abstract}
Abstrak
Tujuan dari penelitian ini untuk mengetahui Efisiensi Pemasaran Lada di Kabupaten Konawe Ditinjau dari Perspektif Ekonomi Islam. Metode penentuan sampel dilakukan dengan cara acak sederhana (sample random sampling) sebanyak 45 responden dari jumlah populasi, sedangkan Pedagang Pengumpul Desa (PPD) diambil sebanyak 3 orang dan Pedagang Pengumpul Kecamatan (PPK) dipilih sebanyak 2 orang secara sensus.

Hasil penelitian disimpulkan bahwa efisiensi pemasaran lada di Kelurahan Unaasi Kecamatan Anggaberi di Kabupaten Konawe melalui 2 saluran pemasaran yaitu: Saluran Pemasaran I, dari Petani Produsen $\rightarrow$ PPK $\longrightarrow$ pedagang antar Pulau, dengan margin pemasaran 97,46 \%. Saluran Pemasaran II, dari Petani Produsen $\rightarrow$ PPD $\longrightarrow$ PPK $\rightarrow$ Pedagang antar Pulau, dengan margin pemasaran $97,40 \%$.

Dari hasil analisis dapat disimpulkan bahwa kegiatan pemasaran pada komoditi lada di Kabupaten Konawe sudah efisien namun perlu ditingkatkan. Dari segi pelayanan sudah memuaskan. Ditinjau dari perspektif ekonomi Islam terhadap komoditi lada yang dilakukan oleh petani/produsen, dilihat dari pemasarannya sudah sesuai dengan dua asumsi yang berada dibawah pengaruh semangat Islam yaitu asumsi rasionalitas ekonomi dan jual beli tanpa adanya paksaan. Karena pemasaran terhadap komoditi lada merupakan upaya-upaya yang dilakukan oleh petani/produsen dalam rangka memaksimumkan kepuasan ekonomi dan pemenuhan kebutuhan. Dalam memasarkan lada yang mereka (petani) hasilkan dengan cara memilih sendiri saluran pemasaran yang mereka inginkan untuk menjual produksi ladanya. Transaksi yang dilakukan oleh petani ini juga insyaAllah terhindar dari transaksi yang bersifat spekulasi, transaksi yang tidak jelas (Gharar), riba dan bathil (perbuatan jahat).
\end{abstract}

Kata kunci : Efisiensi Pemasaran, Ekonomi Islam, dan Lada.

\section{PENDAHULUAN}

Dalam kerangka pembangunan nasional, mandat utama sektor pertanian adalah sebagai penyedia pangan yang cukup bagi penduduknya dan pendukung perkembangan sektor-sektor lainnya. Pada masa mendatang mandat tersebut terasa semakin berat karena laju permintaan terhadap hasil-hasil pertanian terus meningkat sejalan dengan laju pertambahan penduduk dan perbaikan pendapatan per kapita. Permintaan terhadap hasil-hasil pertanian akan meningkat baik dalam jumlah, keragaman, maupun kualitasnya (Suryana A, 2004).

Sektor pertanian mendapat prioritas utama dalam upaya pembangunan ekonomi karena sektor ini merupakan sektor dominan di Indonesia, baik dari kontribusi pada pendapatan nasional, penyediaan 
lapangan kerja, sumber devisa dan lada bagi petani terletak pada nilai sebagainya. Jadi pembangunan pertanian ekonominya yang tinggi. Komoditas lada mempunyai kontribusi yang besar pada pembangunan ekonomi melalui kontribusi produksi bahan makanan dan bahan mentah, kontribusi pasaran hasil dari sektor pertanian, kontribusi faktor produksi tenaga kerja dan modal (Widodo, 2008).

Sub sektor pertanian yang memiliki prospek pengembangan yang cerah dan potensial untuk dikembangkan adalah perkebunan lada rakyat. Lada merupakan salah satu tanaman yang serba guna.kegunaan lada antara lain : (1) sebagai bumbu makanan yang dapat memberi rasa atau menambah selera makan, (2) sebagai bahan obat-obatan dan bahan minyak lada, (3) untuk keperluan pembuatan jamu tradisional. Kenyataan dewasa ini menunjukan bahwa lada merupakan bahan makanan penting, sehingga dapat menjadi sumber pendapatan yang penting pula bagi petani di pedesaan. Berbagai usaha dilakukan untuk memulihkan kembali potensi lada dimana usaha-usaha ini dititikberatkan pada penerapan intensifikasi dan meningkatkan penelitianpenelitian dalam rangka pengembangan lada. Daya tarik pengembangan komoditas sangat besar peranannya dalam menunjang usaha pemerintah untuk meningkatkan pendapatan dan taraf hidup petani, memperluas kesempatan kerja, menunjang pengembangan agribisnis dan melestarikan sumber daya alam (Budianti, 2011).

Kabupaten Konawe saat ini merupakan salah satu daerah yang sangat potensial untuk pengembangan produksi komoditas lada di Sulawesi Tenggara. Petani di Kelurahan Unaasi Kecamatan Anggaberi Kabupaten Konawe melakukan usahatani lada sebagai mata pencaharian utamanya. Tabel potensi produksi lada di Kabupaten Konawe dapat dilihat berikut ini :

Tabel 1. Potensi Lada di Kabupaten

\begin{tabular}{|c|c|}
\hline \multicolumn{2}{|c|}{ Konawe } \\
\hline Produksi 2007 & 182 \\
Produksi 2008 & 1.021 \\
Produksi 2009 & 1.317 \\
Produksi 2010 & 1.441 \\
Produksi 2011 & 851 \\
\hline
\end{tabular}

Sumber: Sulawesi Tenggara dalam angka 2012

Komoditas perkebunan mempunyai prospek cukup baik karena cocok diusahakan dipedesaan dan memiliki nilai ekonomis yang cukup tinggi sehingga mampu meningkatkan pendapatan petani dan memperluas kesempatan kerja di wilayah pedesaan. Pada usaha tani ada 4 
(empat) unsur pokok atau faktor produksi, yaitu tanah, modal, pengelolaan (manajemen), dan tenaga kerja. Apabila keempat unsur ini dapat berjalan dengan baik, diharapkan dapat mengoptimalkan produksi dari suatu usaha tani (Hermanto, 2004).

Lada merupakan salah satu komoditas perkebunan yang digemari masyarakat. Selain dapat dapat sebagai bahan pangan sebagai bumbu masakan dan juga sebagai bahan baku industri. Lada juga merupakan salah satu komoditas perkebunan yang memiliki nilai ekonomi penting di Indonesia, karena buahnya selain dijadikan bumbu masak juga mempunyai kapasitas menaikkan pendapatan petani, sebagai bahan baku industri, memiliki peluang ekspor, dan membuka kesempatan bekerja,

Dalam Islam manusia diwajibkan untuk berusaha agar ia mendapat rezeki guna memenuhi kebutuhan hidupnya. Islam juga mengajarkan kepada manusia bahwa Allah Maha Pemurah sehingga rezekinya sangat luas. Bahkan, Allah tidak memberi rezeki itu kepada muslimin saja, tetapi kepada siapa saja yang bekerja kerasManusia dapat bekerja apa saja, yang penting tidak melanggar garis-garis yang ditentukannya. Ia bisa melakukan aktifitas produksi, seperti pertanian, perkebunan, peternakan, pengelolaan makanan dan minuman, dan sebagainya (Antonio, 2001).

Berdasarkan uraian latar belakang diatas, penelitian ini bertujuan untuk:

1. Untuk mengetahui saluran dan margin pemasaran komoditas lada di Kabupaten Konawe.

2. Untuk mengetahui efisiensi pemasaran komoditas lada di Kabupaten Konawe.

3. Untuk mengetahui bagaimana analisis ekonomi Islam terhadap pemasaran komoditas lada di Kabupaten Konawe.

\section{TINJAUAN PUSTAKA}

\section{A. Analisis Saluran Pemasaran}

Analisis pemasaran dapat dijadikan indikator mengenai sejauh mana perusahaan yang sedang dijalankan telah berjalan dengan efisien. Perhitungan pemasaran dalam perusahaan pertanian relatif lebih kompleks dibandingkan dengan analisis pemasaran dalam perusahaan lain (Padangaran, 2014).

Saluran pemasaran adalah usaha yang dilakukan untuk menyampaikan barang dan jasa dari produsen ke tangan konsemen yang di dalamnya terlibat beberapa lembaga pemesaran yang menjalankan fungsi-fungsi pemasaran (Limbong dan 
Sitorus, 2001). Selanjutnya Kotler (2003) menyatakan bahwa saluran pemasaran adalah serangkaian organisasi yang saling bergantung serta terlibat dalam proses menjadi akan produk atau jasa siap digunakan atau dikonsumsi. Saluran pemasaran yang tidak efisien akan menyebabkan kerugian baik bagi petani maupun konsumen, karena konsumen merasa beban yang berat untuk membayar pada harga tinggi. Sedangkan bagi petani, perolehan pendapatan menjadi lebih rendah karena harga penjualan yang diterima jauh lebih rendah dalam menciptakan pemasaran yang efisien serta menguntungkan bagi petani maupun konsumen, maka petani harus memilih saluran pemasaran yang pendek.

Ada beberapa faktor yang harus dipertimbangkan dalam memilh saluran pemasaran (Limbong dan Sitorus, 2001), yaitu :

1. Pertimbangan pasar yang meliputi konsumen sasaran akhir mencakup pembeli potensial, konsetrasi pasar secara geografis, volume pesanan dan kebiasaan pembeli.

2. Pertimbangan barang yang meliputi nilai barang perunit, besar dan berat barang, tingkat kerusakan, sifat teknis barang ,dan apakah barang tersebut untuk memenuhi pesanan atau pasar.

3. Pertimbangan internal perusahan yang meliputi sumber permodalan, kemampuan dan pengalaman penjualan.

4. Pertimbangan terhadap lembaga perantara, yang meliputi pelayanan lembaga perantara, kesesuaian lembaga perantara dengan kebijaksanaan produsen dan pertimbangan biaya.

\section{B. Margin, Biaya dan Keuntungan Pemasaran}

Margin pemasaran (marketing margin) didefinisikan sebagai perbedaan harga yang terjadi ditingkat petani dan harga yang terjadi tingkat pengecer (Dahl dan Hammond, 2001).

Margin pemasaran sering digunakan dalam analisa efisiensi pemasaran. Margin pemasaran merupakan selisih antara harga ditingkat konsumen dengan harga ditingkat produsen atau merupakan jumlah biaya pemasaran dengan keuntungan yang diharapkan oleh masing-masing lembaga pemesaran. Margin pemasaran pada pola saluran distribusi panjang, sedang maupun pendek berbeda, perbedaan ini disebabkan banyaknya lembaga pemasaran dan tingkat 
keuntungan yang diharapkan (Downey dan Erickson, 2002).

Biaya pemasaran adalah biaya yang dikeluarkan untuk keperluan pemasaran yang meliputi : biaya angkutan, biaya pengeringan, biaya pengepakan retribusi danl ain-lain. Besarnya biaya ini berbedabeda satu sama lainnya tergantung macam komoditinya, lokasi pemasaran macam lembaga pemasaran dan efektifitas pemasaran. Selain itu efesiensi pemasaran berkaitan dengan efektifitas dalam kegiatan fungsi pemasaran dilihat dari segi keuntungan (Soekartawi dalam Yulias, 2010).

Marjin pemasaran mempunyai sifat umum yaitu :

1. Marjin pemasaran berbeda-beda antara satu komoditi hasil pertanian dengan komoditi lainnya.

2. Marjin pemasaran produk pertanian cenderung akan naik dalam jangka panjang dengan menurunnya bagian harga yang diterima petani.

3. Marjin pemasaran relatif stabil dalam jangka pendek terutama dalam hubungannya dengan berfluktuasinya harga produksi hasil pertanian.

\section{Pengertian Pasar dan Pemasaran}

Pasar adalah suatu kegiatan usaha yang mengarahkan arus barang dan jasa dari produsen ke konsumen atau pemakai jasa. Keadaan yang menunjukan kekuatan dari permintaan dan penawaran dari suatu barang atau jasa, secara lebih sederhana pengertian pemasaran pertanian juga diturunkan dari hasil pengertian pemasaran yang diterapkan pada input dan output pertanian misalnya : pemasaran sarana transaksi yakni minat, citra serta daya beli. Produksi bibit, obat pemberantasan hama dan sarana pertanian itu sendiri (Swastha dalam Budiyanti, 2011).

pemasaran adalah suatu proses sosial yang didalamnya melibatkan individu dan kelompok dalam mendapatkan apa yang mereka butuhkan dan inginkan dengan menciptakan, menawarkan dan secara bebas mempertukarkan produk yang bernilai dengan pihak lain (Kotler, 2003). Pemasaran diartikan sama dengan tata niaga atau distribusi yaitu sejenis kegiatan ekonomi yang berfungsi membawa atau menyampaikan barang dari produsen ke konsumen. Disebut Tata niaga karena niaga berarti dagang sehingga segala sesuatu yang menyangkut dalam hal perdagangan barang-barang. Karena perdagangan itu 
biasanya dijalankan melalui pasar maka, tata niaga di sebut pemasaran (Mubyarto dalam Yulias, 2010).

Pemasaran termasuk salah satu kegiatan dalam perekonomian membantu menciptakan nilai ekonomi. Sedangkan nilai ekonomi itu sendiri akan menentukan harga barang dan jasa bagi setiap individu.

\section{Efisiensi Pemasaran}

Sebagaimana kegiatan ekonomi lainnya pemasaran selalu menghendaki adanya efisiensi yaitu pengorbanan yang sekecilkecilnya dari berbagai sumber ekonomi terhadap barang atau jasa yang diminta konsumen. Efisiensi pemasaran dan keuntungan maksimal merupakan tujuan dari perbaikan pemasaran secara mutlak (Nurland,1986).

Dari pernyataan tersebut menunjukan bahwa efisiensi di bidang pemasaran bila memenuhi dua syarat yaitu :

a. Mampu menyampaikan hasil-hasil dari petani produsen pada konsumen dengan biaya yang semurah-murahnya.

b. Mampu mengadakan pembagian yang adil dari keseluruhan harga yang dibayar konsumen terakhir pada semua pihak yang ikut serta dalam kegiatan produksi dan pemasaran itu.
Sedangkan arti kata efisien menurut kamus besar bahasa Indonesia yaitu tepat atau sesuai untuk mengerjakan (menghasilkan) sesuatu (dengan tidak membuang-buang waktu, tenaga, biaya), mampu menjalankan tugas dengan tepat dan cermat, berdaya guna, bertepat guna. Efisiensi adalah penggunaan sumber daya secara minimum guna pencapaian hasil yang optimum.

Pasar yang tidak efisien akan terjadi kalau :

a. Biaya pemsaran yang semakin besar.

b. Nilai produk yang di pasar akan tidak terlalu besar jumlahnya.

Oleh karena itu efisiensi pemasaran akan terjadi kalau:

a. Biaya pemasaran di tekan sehingga keuntungan lebih tingg

b. Tersedianya fasilitas fisik pemasaran.

c. Persentase perbedaan harga-harga yang dibayarkan konsumen dan produsen tidak terlalu tinggi

d. Adanya kompetisi pasar yang sehat.

\section{E. Ekonomi Islam}

Ekonomi merupakan bagian integral dari ajaran Islam, dan karenanya Ekonomi Islam akan terwujud hanya jika ajaran Islam diyakini dan dilaksanakan secara 
menyeluruh. Ekonomi Islam mempelajari perilaku ekonomi individu-individu yang secara sadar dituntun oleh Al-Qur'an dan Sunnah dalam memecahkan masalah yang dihadapinya. Ekonomi Islam adalah sekumpulan dasar-dasar ekonomi yang berdasarkan Al-Quran dan Sunnah yang merupakan bagian perekonomian yang didirikan di atas landasan dasar-dasar tersebut sesuai dengan lingkungan dan masa (Lubis, 2002).

Ekonomi Islam adalah ilmu yang mempelajari segala perilaku manusia dalam memenuhi kebutuhan hidupnya dengan tujuan memperoleh falah (kedamaian dan kesejahteraan dunia-akhirat) atau pengetahuan dan aplikasi ajaran-ajaran dan aturan-aturan syari'ah yang mencegah ketidakadilan dalam pencarian dan pengeluaran sumber-sumber daya, guna memberikan kepuasan bagi manusia dan memungkinkan mereka melaksanakan kewajiban-kewajiban mereka terhadap Allah dan masyarakat (Juniarti, 2011).

Dalam ekonomi Islam, berbagai jenis sumber daya dipandang sebagai pemberian atau titipan Tuhan kepada manusia. Manusia harus memanfaatkan seefisien dan seoptimal mungkin dalam produksi guna memenuhi kesejahteraan bersama yaitu untuk dirinya sendiri dan untuk orang lain. Jadi, ilmu Ekonomi Islam mendasarkan segala aspek tujuan, metode penurunan ilmu, dan nilai-nilai yang terkandung pada agama Islam.

F. Hubungan Antara Efisiensi Pemasaran Komoditas Lada Dengan Ekonomi Islam

Pada dasarnya kegiatan pemasaran harus dilandasi semangat beribadah kepada Tuha Sang Maha Pencipta, berusaha semaksimal mungkin untuk kesejahteraan bersama, bukan untuk kepentingan golongan apalagi kepentingan sendiri. Islam agama yang sangat luar biasa. Islam agama yang lengkap, yang berarti mengurusi semua hal dalam hidup manusia. Islam agama yang mampu menyeimbangkan dunia dan akhirat; antara hablum minallah (hubungan dengan Allah) dan hablum minannas (hubungan sesama manusia). Ajaran Islam lengkap karena Islam agama terakhir sehingga harus mampu memecahkan berbagai masalah besar manusia.

Efisiensi adalah penggunaan sumber daya secara minimum guna pencapaian hasil yang optimum dan efisien ini sangat erat kaitannya dengan biaya yang dikeluarkan. Sedangkan pemasaran sendiri 
adalah suatu kegiatan akhir dari kegiatan ekonomi dalam memuaskan kebutuhan manusia. Bila kedua hal ini dikaitkan dengan ekonomi islam jelas ada kaitannya, di dalam al-qur'an sendiri Allah SWT. sudah mengatakan bahwa kita sebagai manusia harus mempergunakan waktu dengan sebaik-baiknya dengan tidak membuang-buang waktu dengan hal yang tidak berguna.

Di dalam al-qur'an juga Allah sudah menjelaskan untuk tidak membazir-bazir uang untuk hal-hal yang tidak perlu. Bila kedua hal ini dikaitkan dengan pemasaran komoditas lada di Kabupaten Konawe maka dalam memproduksi lada petani atau produsen harus memperhatikan efesiensi dalam hal ini adalah biaya yang dikeluarkan untuk memproduksi lada yang akan dipasarkan. Apabila produksi komoditas lada yang dihasilkan sudah sesuai dengan harapan petani/produsen maka biaya yang dikeluarkan juga akan dapat ditekan sehingga pemasaran yang dilakukan dapat dikatakan efisien.

\section{METODE PENELITIAN}

\section{A. Waktu dan Lokasi Penelitian}

Penelitian ini dilaksanakan mulai bulan September sampai dengan bulan November
2014 di Kelurahan Unaasi Kecamatan Anggaberi Kabupaten Konawe.Pemilihan lokasi penelitian tersebut dilakukan berdasarkan pertimbangan bahwa di Kelurahan Unaasi rata-rata produksi lada meningkatdan sebagian besar petani di Kelurahan tersebu tmengusahakan tanaman lada sebagai pekerjaan pokoknya.

\section{B. Populasi dan Penentuan Sampel}

Populasi dalam penelitian ini adalah semua petani lada di Kelurahan Unaasi Kecamatan Anggaberi yang berjumlah 100 orang. Penentuan sampel dilakukan dengan cara acak sederhana (sample random sampling) sebanyak 45 responden dari jumlah populasi. Dengan rumus menurut Slovin (Slovin dkk, 1993) yaitu sebagai berikut :

$$
\begin{gathered}
\mathrm{N} \\
\mathrm{n}=\ldots \ldots . . . \\
1+\mathrm{N}(\mathrm{e}) \\
100 \\
\mathrm{n}=\ldots \ldots \ldots \ldots . . . \\
1+100(0,11)^{2} \\
=1+100(0,0121) \\
=1+1,21 \\
100 \\
\mathrm{n}=\ldots \ldots . . . \\
2,21
\end{gathered}
$$

Keterangan:

$\mathrm{n}=$ Jumlah sampel 
$\mathrm{N}=$ Jumlah Populasi

$\mathrm{E}=$ Persentase kelonggaran $11 \%(0,11)$

Sedangkan Pedagang Pengumpul Desa diambil sebanyak 3 orang dan Pedagang Pengumpul Kecamatan dipilih sebanyak 2 orang secara sensus.

\section{Jenis dan Sumber Data}

Data penelitian ini terdiri dari data primer dan data sekunder, pengumpulan data dilakukan dengan cara : (1) wawancara, yaitu mengadakan wawancara langsung dengan obyek penelitian untuk mengumpulkan data dan informasi yang diperlukan dengan menggunakan daftar pertanyaan yang telah disiapkan terlebih dahulu, (2) pencatatan yaitu mencatat data yang sudah tersedia di kantor-kantor atau instansi terkait dengan penelitian.

\section{Metode Analisis Data}

Data yang diperoleh ditabulasi dan dianalisis berdasarkan distribusi dan ratarata hitung.

a. Untuk mengetahui saluran pemasaran, margin dan efisiensi pemasaran dari produsen ke konsumen dengan menggunakan rumus yaitu :

Untuk mengetahui margin pemasaran :

$$
\text { M = He-Hp (Nurland,1986). }
$$

Keterangan :

$$
\begin{aligned}
\mathrm{M}= & \text { Margin pemasaran }(\mathrm{Rp} / \mathrm{Kg}) \\
\mathrm{He}= & \text { Harga eceran pedagang }(\mathrm{Rp} / \mathrm{Kg}) \\
\mathrm{Hp}= & \text { Harga beli ditingkat petani } \\
& (\mathrm{Rp} / \mathrm{Kg})
\end{aligned}
$$

Sedangkan besarnya keuntungan yang diperoleh setiap lembaga pemasaran dapat dihitung dengan rumus :

$$
\mathrm{M}=\mathrm{B}+\pi \text { atau } \pi=\mathrm{M}-\mathrm{B}
$$

(Nurland,1986)

\section{Keterangan=}

$\mathrm{Q}$ = Besarnya keuntungan ( $\mathrm{Rp} / \mathrm{Kg})$

$\mathrm{B}=$ Biaya pemasaran $(\mathrm{Rp} / \mathrm{Kg})$

$\mathrm{M}=$ Marjin pemasaran $(\mathrm{Rp} / \mathrm{Kg})$

Sehinggga analisis efisiensi pemasaran adalah sebagai berikut :

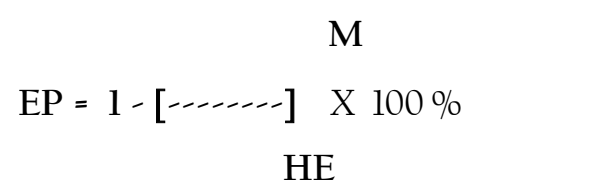

(Nurland, 1986 )

\section{Keterangan :}

EP = Persentase yang diterima petani dari harga dibayarkan oleh konsumen akhir.

$\mathrm{M}=$ Margin pemasaran

$\mathrm{HE}=$ Harga ditingkat pedagang

- Jika EP < 50\% maka pemasaran lada tidak efisien

- Jika EP > 50\% maka pemasaran lada efisien 
Untuk analisis yang ketiga menggunakan metode deskriptif kualitatif kemudian diperoleh kesimpulan dari permasalahan penelitian ini.

\section{HASIL DAN PEMBAHASAN}

\section{A. Gambaran Umum Daerah Penelitian}

Kelurahan Unaasi terletak di Kecamatan Anggaberi Kabupaten Konawe dengan luas wilayah 2264 Ha dan jarak kurang lebih 8 kilometer dari Ibukota Kecamatan dan 9 kilometar dari Ibukota Kabupaten Konawe dan 75 kilometer dari Ibukota Provinsi. Secara geografis kelurahan Unaasi terletak diantara 5,15으 - 5,2은 LS dan diantara $122,36^{\circ}$ - 122,00 $\mathrm{O}$ BT, dengan kondisi topografi dataran rendah dengan batasan-batasan wilayah sbb :

- Sebelah utara berbatasan dengan Kelurahan Lawulo

- Sebelah selatan berbatasan dengan Kelurahan Parauna

- Sebelah timur berbatasan dengan Kelurahan Parauna

- Sebelah barat berbatasan dengan Kelurahan Kulahi

Berdasarkan hasil survey yang dilakukan selama penelitian ini diketahui secara umum keadaan wilayah Kelurahan Unaasi komoditi perkebunan yang paling banyak diusahakan oleh petani adalah lada. Untuk mengetahui berbagai macam

komoditas pertanian perkebunan di Kelurahan Unaasi Kecamatan Anggaberi Kabupaten Konawe dilihat pada tabel 2 berrikut ini :

Tabel 2. Keadaan Tanaman Perkebunan di KelurahanUnaasi 2014.

\begin{tabular}{|l|l|c|}
\hline No. & Jenis Tanaman & Luas Areal $(\mathrm{Ha})$ \\
\hline l. & Lada & 182,5 \\
2. & Kelapa dalam & 25,5 \\
3. & Jambu mete & 52 \\
4. & Kakao & 33 \\
5. & Sagu & 8 \\
\hline \multicolumn{2}{|c|}{ Jumlah } & 301 \\
\hline
\end{tabular}

Sumber : Data Skunder di Kantor Kelurahan Unaasi, Tahun 2014

Berdasarkan dari Tabel 2 menunjukkan bahwa lada merupakan tanaman perkebunan yang paling banyak diusahakan oleh petani di Kelurahan tersebut yaitu tanaman lada $182,5 \mathrm{Ha}$. Proses mengelola usaha perkebunannya, petani memperoleh informasi tentang teknologi baru dari berbagai sumber informasi pertanian, namun pada umumnya mereka tidak langsung menerapkan. Penyebaran teknologi baru memerlukan waktu untuk diterapkan, disebabkan karena kemampuan setiap petani dalam menerapkan teknologi baru berbeda-beda. Kemampuan yang berbeda-beda tersebut didasari oleh beberapa faktor dan dalam 
kaitannya dengan penerapan teknologi usaha perkebunan lada.

Lahan garapan yang dimaksud dalam penelitian ini adalah lahan yang dipergunakan untuk usahatani. Luas lahan garapan merupakan salah satu faktor produksi yang menentukan pengambilan keputusan dan keberhasilan seorang petani dalam melaksanakan usahataninya. Makin luas lahan garapan yang dimiliki oleh petani maka makin bebas petani tersebut dalam mengelola lahan untuk diusahakan. Makin luas lahan garapan berarti pula makin banyak input yang diperlukan untuk mengelola lahan tersebut dan lebih banyak membutuhkan tenaga kerja. Sedangkan lahan yang sempit kebutuhan tenaga dan input yang dibutuhkan untuk mengelola usahataninya juga sedikit. Dari hasil penelitian dilapangan petani responden memiliki luas lahan garapan yang berbedabeda Di daerah penelitan berdasarkan hasil survey mayoritas petani yang mengusahakan tanaman lada adalah beragama Islam.

\section{B. Analisis Pemasaran Komoditas Lada}

\section{Jumlah Produksi}

Produksi yang dimaksudkan dalam penelitian ini adalah produksi lada petani responden selama satu kali musim panen, produksi lada yang diperoleh petani responden dapat dilihat pada Tabel 3 berikut ini :

Tabel 3. Keadaan Jumlah Produksi Lada

Petani Responden di KelurahanUnaasi

\begin{tabular}{|c|c|c|c|}
\hline No. & $\begin{array}{c}\text { Jumlah } \\
\text { Produksi } \\
\text { Lada (Kg) }\end{array}$ & $\begin{array}{c}\text { Jumlah } \\
\text { (Jiwa) }\end{array}$ & $\begin{array}{c}\text { Persentase } \\
\text { (\%) }\end{array}$ \\
\hline 1 & $<442$ & 11 & 24,44 \\
2 & $>442$ & 34 & 75,55 \\
\hline & Jumlah & 45 & 100,00 \\
\hline
\end{tabular}

Sumber : Hasil Olahan Data Primer Tahun 2014

\section{Saluran Pemasaran}

Di lokasi penelitian komoditi lada yang dihasilkan oleh petani produsen dijual kepada para konsumen melalui beberapa saluran pemasaran. Adapun saluran pemasaran lada yang ada di Kelurahan Unaasi Kecamatan Anggaberi Kabupaten Konawe adalah sebagai berikut:

Saluran Pemasaran I :

Petani Produsen $\rightarrow$ PPK $\rightarrow$ Pedagang antar pulau

Saluran Pemasaran II:

Petani Produsen $\rightarrow$ PPD $\rightarrow$ PPK

$\rightarrow$ Pedagang antar pulau

Keterangan :

PPK = Pedagang Pengumpul Kecamatan PPD = Pedagang Pengumpul Desa

Saluran pemasaran I, petani langsung menjual ke Pedagang Pengumpul 
Kecamatan dengan harga Rp 77.000,-/Kg harga Rp. 78.000,-/Kg. Dari kedua saluran selanjutnya Pedagang Pengumpul pemasaran lada tersebut diatas, maka Kecamatan menjual ke Surabaya dengan saluran pemasaran I paling banyak harga Rp. 78.000,-/Kg. Pada saluran digunakan oleh petani responden di pemasaran II petani 1 menjual ke Pedagang Kelurahan Unaasi Kecamatan Anggaberi Pengumpul Desa dengan harga Rp 75.000,- Kabupaten Konawe. Untuk lebih jelasnya /Kg dan Pedagang Pengumpul Desa mengenai jumlah petani responden di menjual ke Pedagang Pengumpul Kelurahan Unaasi Kecamatan Anggaberi Kecamatan dengan harga $\mathrm{Rp} 77.000,-/ \mathrm{Kg}$ yang memasarkan lada dapat disajikan selanjutnya Pedagang Pengumpul pada tabel 4 berikut.

Kecamatan menjual ke Surabaya dengan

Tabel 4. Harga dan Jumlah Produsen yang Memasarkan Lada Kepada Lembaga Pemasaran Di Kabupaten Konawe.

\begin{tabular}{|c|c|c|c|c|}
\hline No. & Uraian & $\begin{array}{c}\text { Harga } \\
(\mathrm{Rp} / \mathrm{Kg})\end{array}$ & $\begin{array}{c}\text { Jumlah } \\
\text { (Jiwa) }\end{array}$ & $\begin{array}{l}\text { Persentase } \\
(\%)\end{array}$ \\
\hline 1. & Pedagang PengumpulDesa & 75.000 & 19 & 42,22 \\
\hline 2. & $\begin{array}{l}\text { Pedagang Pengumpul } \\
\text { Kecamatan }\end{array}$ & 77.000 & 26 & 57.78 \\
\hline & Jumlah & & 45 & 100,00 \\
\hline
\end{tabular}

Sumber : Hasil Olahan Data Primer Tahun 2014

Tabel 5 terlihat bahwa harga beli terendah adalah di Pedagang Pengumpul Desa yaitu Rp.75.000/Kg dan tertinggi pada Pedagang Pengumpul Kecamatan Rp.77.000/Kg,- . Harga jual terendah pada Pedagang Pengumpul Desa yaitu Rp.77.000,-/Kg dan tertinggi pada Pedagang Pengumpul Kecamatan yaitu Rp.79.000,-/Kg. Biaya terendah pada Pedagang Pengumpul Desa yaitu Rp.150,-/Kg dan tertinggi pada Pedagang Pengumpul Kecamatan yaitu Rp.350,-/Kg. Keuntungan terendah yang diperoleh pedagang terdapat pada Pedagang Pengumpul Kecamatan dengan keuntungan sebesar Rp.1.650,/Kg dan tertinggi pada Pedagang Pengumpul Desa yaitu Rp 1.850,-/Kg, hal ini disebabkan karena harga beli pada Pedagang Pengumpul Desa yang relatif rendah jika dibandingkan harga beli pada Pedagang Pengumpul Kecamatan meskipun margin kedua lembaga pemasaran tersebut sama. 
C. Bagian yang Diterima Petani pemasaran yang digunakan tidak efisien.

\section{(Efisiensi Pemasaran)}

Bagian harga yang diterima petani responden dalam merupakan gambaran efisien tidaknya jalur pemasaran yang digunakan. Persentase bagian harga yang diterima petani responden kurang dari 50 $\%$ dapat dikatakan bahwa saluran

Tabel 6. Persentase Bagian Harga yang Diterima Petani Responden

Di Kelurahan Unaasi, Kabupaten Konawe.

\begin{tabular}{|c|c|c|c|c|c|}
\hline No. & $\begin{array}{c}\text { Saluran } \\
\text { Pemasaran }\end{array}$ & $\begin{array}{c}\text { Harga yang } \\
\text { Diterima Produsen } \\
(\mathrm{Rp} / \mathrm{Kg})\end{array}$ & $\begin{array}{c}\text { Margin } \\
\text { Pemasaran } \\
(\mathrm{Rp} / \mathrm{Kg})\end{array}$ & $\begin{array}{c}\text { Harga yang } \\
\text { Dibayarkan } \\
\text { Pedagang } \\
(\mathrm{Rp} / \mathrm{Kg})\end{array}$ & $\begin{array}{c}\text { Bagian Harga } \\
\text { Yang Diterima } \\
\text { Petani } \\
(\%)\end{array}$ \\
\hline 1. & I & 77.000 & 2000 & 79.000 & 97,46 \\
\hline 2. & II & 75.000 & 2000 & 79.000 & 97,40 \\
\hline
\end{tabular}

Sumber: Hasil Olahan Data Primer Tahun 2014.

Dari tabel 6 diatas nampak bahwa pada saluran pemasaran I persentase bagian harga yang diterima petani dari harga yang dibayarkan pedagang sebesar 97,46\%, pada saluran pemasaran II persentase bagian harga yang diterima petani dari harga yang dibayarkan Pedagang Pengumpul Kecamatan sebesar 97,40 \%. Dari kedua saluran pemasaran tersebut diketahui bahwa saluran pemasaran I merupakan saluran pemasaran yang paling efisien.

\section{Pemasaran Lada Di Kabupaten Konawe Menurut Perspektif Ekonomi Islam}

Pemasaran dalam perspektif ekonomi Islam adalah sebuah disiplin strategi yang mengarahkan proses penciptaan, penawaran dan perubahan value dari suatu inisiator kepada stakeholdernya yang dalam keseluruhan prosesnya sesuai dengan akad-akad dan prinsip-prinsip muamalah dalam Islam. Pemasaran adalah bagian dari aktifitas atau kegiatan jual beli. Pada dasarnya Islam sangat menghargai mekanisme dalam perdagangan. Penghargaan tersebut berangkat dari ketentuan Allah SWT, bahwa perniagaan harus dilakukan secara baik dan dengan rasa suka sama suka ( mutual goodwill), 
Maksudnya, jangan mengkhianati apa-apa yang telah disepakati dalam bisnis. Rasulullah SAW sangat menekankan pentingnya integritas dalam menjalankan bisnis apalagi seorang pemasar yang katanya menjadi ujung tombak dan menjadi seorang patron performance perusahaan di mata konsumen.

Pemasaran syari'ah adalah bahwa dalam seluruh proses baik proses penciptaan proses penawaran, maupun proses perubahan nilai-nilai tidak boleh ada halhal yang bertentangan dengan akad dan prinsip-prinsip muamalah dalam Islam. Sepanjang hal tersebut dapat di jamin, dan penyimpangan prinsip-prinsip muamalah tidak akan terjadi, maka bentuk transaksi apapun dalam bisnis dibolehkan dalam syari'at Islam. Karena itu, Allah SWT mengingatkan agar senantiasa menghindari perbuatan zalim dalam bisnis termasuk dalam proses penciptaan, penawaran dan proses perubahan nilai dalam pemasaran. Patut diakui bahwa dalam ilmu ekonomi perilaku konsumen muslim tidak bisa dipisahkan dari pergerakan pasar karena hubungan konsumen dan produsen dalam pasar saling berhubungan satu sama yang lain. Rasulullah melarang harga yang direkayasa agar menguntungkan pedagang.
Sering kali oleh karena ingin untung besar sekelompok pedagang sengaja menimbun barang supaya harganya melonjak. Jelas sekali praktek ini merugikan banyak pihak.

Islam menghalalkan umatnya berniaga. Bahkan Rasulullah Shallallahu 'alaihi wa sallam seorang saudagar sangat terpandang pada zamannya. Sejak muda beliau dikenal sebagai pedagang jujur. "Sepanjang perjalanan sejarah, kaum Muslimin merupakan simbol sebuah amanah dan di bidang perdagangan, mereka berjalan di atas adab islamiah". Rasulullah Shallallahu 'alaihi wa sallam telah mengajarkan pada umatnya untuk berdagang dengan menjunjung tinggi etika keislaman. Dalam beraktivitas ekonomi, umat Islam dilarang melakukan tindakan bathil. Oleh sebab itu, sasaran yang hendak dicapai dari pergerakan pasar menurut perspektif ekonomi Islam ialah kebahagiaan bagi semua manusia, dalam hal ini terdiri dari produsen dan konsumen, tanpa mencederai suatu pihak manapun. Kebahagiaan adalah keinginan semua manusia, dia akan dicapai manakala manusia mampu membatasi dirinya terhadap bentuk-bentuk kemungkaran. Bisnis yang sesuai dengan syariat Islam berlandaskan iman kepada 
allah SWT dan Rasul-Nya dan menjauhi larangan Allah SWT dan Rasul-Nya. Strategi bisnis yang sesuai syari'ah adalah berupaya dengan sungguh-sungguh dijalan Allah SWT dengan mengelola sumber daya secara optimal untuk mencapai tujuan yang terbaik disisi Allah SWT, baik di dunia maupun diakhirat. Disamping bentuk usaha, pemasaran juga merupakan hal yang menjadi perhatian dalam Islam.

Dengan kata lain tidak ada pihak yang dirugikan. untuk menegakkan prinsip tata niaga yang berdasarkan prinsip syari'ah ini, maka praktek riba, gharar dan maisir harus dihilangkan. Riba secara bahasa berarti ziyadah ( tambahan). Dalam pengertian lain, secara linguistic riba juga berarti tumbuh dan membesar. Sedangkan menurut istilah teknis, riba berarti pengambilan tambahan dari harta pokok atau modal secara bathil. Gharar adalah suatu transaksi yang mendukung ketidak pastian yang menduga kedua belah pihak yang melakukan transaksi sebagai akibat dari dari diterapkannya kondisi ketidakpastian dalam suatu akad yang secara alamiyah nya seharusnya mengandung kepastian. Sedangkan maisir didefenisikan sebagai suatu permainan peluang atau suatu permainan ketangkasan dimana salah satu pihak atau beberapa pihak harus menanggung beban pihak lain sebagai suatu konsekuensi keuangan akibat hasil dari permainan tersebut.

Sistem pasar yang berada di bawah pengaruh semangat Islam berdasarkan 2 (dua) asumsi yaitu rasionalitas ekonomi dan persaingan sempurna. Yang dimaksud dengan rasionalitas ekonomi adalah upayaupaya yang dilakukan oleh produsen dan konsumen dalam rangka memaksimumkan kepuasaannya masing-masing. Dalam hal ini bermakna bahwa tujuan konsumen adalah memaksimumkan kepuasan dan tujuan pengusaha adalah memaksimumkan keuntungan. Pencapaian kepuasan tersebut tentunya haruslah diproses dan ditindak lanjuti secara berkesinambungan dan masing-masing pihak hendaknya mengetahui dengan jelas apa dan bagimana keputusan yang harus diambil dalam pemenuhan kebutuhan ekonomi tersebut. Persaingan sempurna adalah munculnya sebanyak mungkin produsen dan konsumen di pasar, barang yang ada bersifat heterogen dan faktor produksi bergerak secara bebas. Berdasarkan asumsi ini, sistem pasar dibawah pengaruh semangat Islam dapat dianggap sempurna. 
Dari uraian tersebut, jika dikaitkan dengan efsiensi pemasaran lada di Kabupaetn Konawe, Kecamatan Anggaberi Kelurahan Unaasi sudah sesuai dengan dua asumsi tersebut, karena pemasaran terhadap komoditi lada merupakan upayaupaya yang dilakukan oleh petani sebagai produsen adalah dalam rangka memaksimumkan kepuasan ekonomi dan pemenuhan kebutuhan baik bagi petani sebagai produsen maupun bagi pembeli sebagai konsumen. Dalam sistem ekonomi Islam, pasar yang ada berdasarkan atas etika dan nilai-nilai syari'ah baik dalam bentuk perintah, larangan, anjuran, ataupun himbauan. Pelaku pasar mempunyai tujuan utama dalam melakukan sebuah transaksi, yaitu mencapai ridha Allah demi mewujudkan kemaslahatan hidup bersama disamping kesejahteraan individu.

Dalam usaha memasarkan produksinya (ladaI yang dihasilkan oleh petani lada, kadang-kadang atau seringkali para petani mengalami kendala-kendala dalam memasarkan hasil pertaniaanya, dalam hal ini lada. Kesulitan yang biasa di alami yaitu tidak adanya fasilitas kendaraan yang akan digunakan dalam mengangkut hasil produksi ladanya. selain itu jarak tempat memasarkan hasil ladanya yang dirasakan cukup jauh ke kecamtan. Sebenarnya dalam memasarkan hasil ladanya, petani dapat menjual ke pedagang pengumpul desa yang biasanya bisa langsung ke petani-petani lada. Tetapi biasanya harga yang ditawarkan oleh pedagang pengumpul desa relarif lebih murah, sehingga biasanya jika hasil produksi lada dirasa cukup banyak maka petani menjualnya langsung ke pedagang pedagang kecamatan dengan harapan dapat mendapatkan keuntungan sehingga dapat meningkatkan pendapatan petani lada, dengan demikian harapan petani lada untuk meningkatkan tingkat kesejahteraan rumah tangganya dapat terpenuhi.

Dalam melakukan pemasaran hasil ladany, persaingan ditingkat petani dapat dikatakan sangat minim, mengingat produksi lada di daerah Kabupaten Konawe yang masih kurang karena hanya beberapa desa/kelurahan yang berpotensi untuk menanam tanaman lada. Sehingga secara umum dapat dikatakan persaingan dalam memasarkan hasil produksi ladanya, sudah dapat dikatakan sempurna karena di sini petani sebagai produsen lada selalu menjual ladanya dengan pilihan-pilihan yang telah ada. Dimana petani dapat 
menjual ladanya ke pedagang pengumpul desa atau ke pedagang pengumpul kecamatan tanpa ada paksaan atau intimidasi pihak manapun. Jadi petani dapat memilih mau yang dekat atau praktis yaitu ke pedagang pengumpul desa tetapi dengan harga yang relatif murah atau pilihan ke dua yaitu menjualnya ke pedagang pengumpul kecamatan dengan harga yang lebih tinggi dari pada pilihan yang pertama. Berdasarkan salah satu prinsip dalam ekonomi Islam bahwa dimana dalam tataniagan atau perdagangan tidak ada paksaan dan dilakukan secara sukarela, maka sistem pemasaran atau tata niaga tersebut sudah sesuai dengan prinsip syari'ah. Kegiatan pemasaran tersebut membutuhkan sebuah konsep pemasaran yang mendasar sesuai dengan kepentingan pemasar dan kebutuhan serta keinginan pelanggan.

Sistem pemasaran lada di Kabupaten Konawe, ini juga terhindar dari unsur riba dan gharar, karena baik produsen (petani lada) dan konsumen (pedagang pengumpul desa dan pedagang pengumpul kecamatan) sendiri yang menentukan dan memilih sendiri jenis lada yang mereka inginkan. Masalah harga juga sudah disepakati atau sudah diketahui dari awal antara penjual dan pembeli. Jadi sedikit pun tidak mengandung unsur riba dan ketidak jelasan terhadap produk yang akan dijual atau dibeli tersebut, sehingga pemasaran yang dilakukan oleh petani (produsen) sudah sesuai berdasarkan perspektif ekonomi Islam. Sekalipun tidak ada persaingan yang sangat singnifikan dan menentukan harga secara besaran nominal yang signifikan, keuntungan yang wajar dalam perdagangan atau pemasaran (dalam hal ini pemasaran komoditi lada), namun dengan tegas Al-Qur'an berpesan, agar pengambilan keuntungan dilakukan secara fair, saling ridha dan menguntungkan.

Sebagaimana Firman Allah QS. AnNisa': 29 sebagai berikut :

Artinya; "Wahai orang-orang yang beriman, janganlah kamu saling memakan harta sesamamu dengan jalan yang batil (tidak benar), kecuali dalam perdagangan yang berlaku atas dasar suka sama suka di antara kamu. Dan janganlah kamu membunuh dirimu. Sungguh, Allah Maha Penyayang kepadamu. (QS.An-Nisa'29).

Dalam melakukan pemasaran seorang pengusaha/produsen/petani juga harus memikirkan apakah pemasaran yang dilakukannya sudah efisien atau belum. Sebuah perusahaan/produsen/petani dalam memproduksi dan memasarkan produk 
yang mereka produksi harus menjelaskan agar manusia tidak bersifat memperhatikan biaya yang dikeluarkan terlalu kikir dan jangan juga terlalu dan hasil yang diharapkan, agar pemasaran tersebut bisa dilakukan seefisien mungkin. pemurah. Allah juga mengatakan janganlah Efisiensi adalah kemampuan untuk manusia itu terlalu kikir tak mau member menyelesaikan suatu pekerjaan dengan suatu apapun kepada siapa pun dan jangan benar. Dalam perusahaan, usaha terlalu berlebihan dalam membelanjakan meningkatkan efisiensi umumnya harta, kamu berikan harta itu melebihi dihubungkan dengan biaya yang kecil untuk memperoleh hasil tertentu atau biaya tertentu untuk hasil yang banyak. Ini berarti pemborosan di tekan sekecil mungkin dan sesuatu yang memungkinkan untuk mengurangi biaya ini dilakukan dengan efisien.

Sebagaimana Allah berfirman dalam surat Al-Isra' ayat 26 dan 29 yang berbunyi :

Artinya : "Dan janganlah kamu jadikan tanganmu terbelenggu pada lehermu dan janganlah kamu terlalu mengulurkannya. Karena itu kamu menjadi tercela dan menyesal".

Kedua ayat ini sangat erat hubungannya dengan efisiensi yang mana kedua ayat ini melarang manusia untuk menghambur-hamburkan harta yang mereka miliki untuk hal-hal yang tidak berguna seperti berbuat maksiat dengan harta yang mereka miliki dan memberikannya kepada orang yang tidak patut menerimanya. Dan ayat ini juga kemampuanmu dan kamu keluarkan lebih dari pengeluaranmu. Karena jika kamu bakhil maka kamu akan menjadi orang yang tercela dan terhina dihadapan manusia. Kesimpulannya adalah berhematlah kamu dalam hidupmu, berlakulah dalam membelanjakan harta, janganlah jadi orang yang bakhil dan jangan pula menjadi orang yang berlebih-lebihan.

\section{KESIMPULAN DAN SARAN}

\section{A. Kesimpulan}

1. Saluran pemasaran lada di Kelurahan Unaasi Unaasi Kecamatan Anggaberi Kabupaten Konawe melalui 2 saluran pemasaran yaitu :

> Saluran Pemasaran I : dari Petani Produsen $\longrightarrow \mathrm{PPK} \longrightarrow$ pedagang antar Pulau, dengan margin pemasaran $97,46 \%$

Saluran Pemasaran II : dari Petani Produsen $\longrightarrow$ PPD $\longrightarrow$ $\mathrm{PPK} \rightarrow$ Pedagang antar Pulau, dengan margin pemasaran $97,40 \%$. 
2. Dari hasil analisis dapat disimpulkan bahwa kegiatan pemasaran pada komoditi lada di Kabupaten Konawe sudah efisien namun perlu ditingkatkan.

3. Perspektif ekonomi Islam terhadap komoditi lada yang dilakukan oleh petani/produsen, dilihat dari pemasarannya sudah sesuai dengan dua asumsi yang berada dibawah pengaruh semangat Islam yaitu asumsi rasionalitas ekonomi dan jual beli tanpa adanya paksaan. Karena pemasaran terhadap komoditi lada merupakan upaya-upaya yang dilakukan oleh petani/produsen dalam rangka memaksimumkan kepuasan ekonomi dan pemenuhan kebutuhan. Dalam memasarkan lada yang mereka (petani) hasilkan dengan cara memilih sendiri saluran pemasaran yang mereka inginkan untuk menjual produksi ladanya. Transaksi yang dilakukan oleh petani ini juga insyaAllah terhindar dari transaksi yang bersifat spekulasi, transaksi yang tidak jelas (Gharar), riba dan bathil (perbuatan jahat).

\section{B. Saran}

1. Bagi petani/produsen yang ingin menjual hasil petaniannya (dalam hal ini lada) dapat memilih saluran pemasaran yang dianggap paling efektif dan efisien sehingga dapat meningkat tingkat pendapatan dan kesejahteraan petani.

2. Bagi pemerintah agar lebih memperhatikan dan tetap mengawasi perkembangan sistem pemasaran lada agar tidak terjadi kesenjangan harga dan kecurangan dalam penentuan harga dan spekulasi harga dipihak pedagang yang akan membeli hasil produksi lada.

3. Diharapkan untuk kedepan kepada sarjana ekonomi Islam dan pihak-pihak yang mendalami hukum Islam untuk bisa memberikan pencerahan serta sosialisasi tentang pentingnya pemasaran secara Islami.

\section{DAFTAR PUSTAKA}

Ayub, M Padangaran, 2014. Analisis Kuantitatif Pembiayaan Perusahaan Pertanian. PT. Penerbit IPB Press. 2014.

Budiyanti, 2011. Analisis Pemasaran Lada (Piper ningrum) di Kecamatan Unaaha Kabupaten Konawe. Skripsi Unilaki. Dalh, D.C, and J.W. Hammond, 2002. Market and Price Analysis The Agricultural Industries, Mc Graw,. Hill Book Company. New York.

Departemen Agama RI, Al-Qur'an dan Terjemahannya, (Surabaya: PT. Toha Putra, 1999). 
Downey, W.D. dan S.P. Erickson, 2002. Manajemen Agribisnis. Edisi kedua. Erlangga, Jakarta. (Terjemahan : oleh Rochidayat).

Hermanto, 2004. Ilmu Usaha Tani, Ed. X,h. 44. Penerbit Penebar Swadaya. Jakarta.

Juniarti, 2011. Efektifitas dan Efisiensi Pemasaran Meubel CV. Pasaman Rantau Jaya Industri Dumai Menurut Perspektif Ekonomi Islam. Skripsi Jurusan Ekonomi Islam UIN Sultan Syarif Kasim Riau. Pekan Baru.

Kotler, 2003. Manajemen Pemasaran: Analisis Perencanaan, Implementasi, dan Pengendalian. Edisi Keenam jilid 1. Penerbit Erlangga. Jakarta.

Limbong, W,M. dan P. Sitorus, 2001. Pengantar pemasaran Pertanian. Bahan kuliah Jurusan Ilmu-Ilmu Social Ekonomi Pertanian IPB. Bogor.
Lubis,H.Ibrahim. Ekonomi Islam Suatu Pengantar. (Jilid I; Jakarta: Penerbit Kalam Mulia, 2002)

Nurland, F. 1986. Pemasaran Produksi Pertanian. LEPHAS.Ujung Pandang.

Mubyanto, 2007. Pengantar Ekonomi Pertanian. LP3ES. Jakarta.

Muhammad Syafi'I Antonio, 2001. Bank Syariah Dari teori Ke Praktek. Penerbit Gema Insani. Jakarta.

Yulias, 2010. Analisis Sistem Pemasaran Komoditi Lada di Kelurahan Unaaha Kecamatan Unaaha Kabupaten Konawe. Skripsi Universitas Lakidende. 